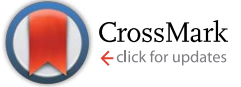

Cite this: RSC Adv., 2017, 7, 16561

Received 16th January 2017

Accepted 6th March 2017

DOI: $10.1039 / \mathrm{c} 7 \mathrm{ra00664k}$

rsc.li/rsc-advances

\section{Oxidative cross-coupling reaction by scandium catalysis for synthesis of $\alpha$-alkyl $\alpha$-amino acid ester derivatives $\uparrow$}

\author{
Xiao-Hong Wei, ${ }^{\star}$ Lian-Biao Zhao* and Han-Cheng Zhou
}

A novel oxidative cross-coupling reaction between $N$-arylglycine esters and alkyl boronic acid esters for synthesis of $\alpha$-alkyl $\alpha$-amino acid esters in the presence of scandium catalysis using silver salt as an oxidant has been developed. The mild reaction has an excellent functional group tolerance and gives the desired $\alpha$-alkyl $\alpha$-amino acid esters in a moderate to excellent yield.
In the past decade, the oxidative coupling reaction has become a new method to afford $\mathrm{C}-\mathrm{C}$ bonds from $\mathrm{C}-\mathrm{H}$ bonds due to it being atom economical and environmentally friendly. ${ }^{1}$ Meanwhile, $\alpha$-amino acids play an important role in natural products and are the key structural motifs of numerous natural products. ${ }^{2}$ Therefore, the oxidative coupling reaction of glycine derivatives has gained significant attention for the synthesis of a series of $\alpha$-substituted $\alpha$-amino acid derivatives. ${ }^{3}$ For example, Li's group designed the first method for an oxidative dehydrogenative coupling reaction to synthesize $\alpha$-amino glycine derivatives from $\mathrm{N}$-glycine derivatives by direct $\mathrm{C}-\mathrm{C}$ bond formation. ${ }^{3 a}$ Subsequently, Huang's group disclosed a crossdehydrogenative coupling reaction with $\mathrm{N}$-arylglycine esters to synthesize $\alpha$-amino glycine derivatives under the cooperative catalysis of copper salt. ${ }^{3 b}$ Recently, the oxidative coupling of $\mathrm{N}$ glycine derivatives has been well developed under stoichiometric amounts of chemical oxidants such as DTBP, DDQ, TBHP and 2,2,6,6-tetramethylpiperidine-1-oxoammonium tetrafluoroborate $\left(\mathrm{T}^{+} \mathrm{BF}_{4}{ }^{-}\right) \cdot{ }^{4}$ Furthermore, transition metal-catalyzed synthesis of chiral $\alpha$-amino acid derivatives by direct $\mathrm{C}-\mathrm{H}$ oxidative cross-coupling has been reported in the past few years. ${ }^{5}$ For example, Wang's group developed a significant method of chiral Lewis acid controlled enantioselective alkyl-

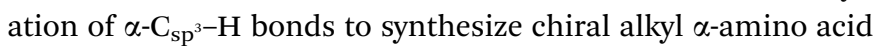
derivatives. ${ }^{6}$ Another effective pathway to synthesize chiral $\alpha$ amino acids has been reported by palladium-catalyzed $\mathrm{C}-\mathrm{H}$ functionalization. ${ }^{7}$ Recently, Yang's group found a novel pathway for the synthesis of chiral $\alpha$-amino acid derivatives from aryl boronic acids by $\mathrm{Pd}(\mathrm{II})$-catalysis with direct $\mathrm{C}-\mathrm{H}$ oxidation (1, Scheme 1$),{ }^{5 g}$ but only $\alpha$-aryl $\alpha$-amino acid ester

Key Laboratory for Utility of Environment-Friendly Composite Materials and Biomass in University of Gansu Province, College of Chemical Engineering, Northwest University for Nationalities, Lanzhou 730030, P. R. China. E-mail: weixh12@lzu. edu.cn; 1146868630@qq.com

$\dagger$ Electronic supplementary information (ESI) available. See DOI: $10.1039 / \mathrm{c} 7 \mathrm{ra} 00664 \mathrm{k}$ derivatives were obtained. However, for the synthesis of benzyl $\alpha$-amino acid derivatives by the oxidative cross-coupling reaction of glycine derivatives, very few examples have been reported to date. ${ }^{8}$ Based on this considerable progress, in this paper, we describe a novel strategy for the cross-coupling reaction between $N$-arylglycine esters and boronic acid esters for the synthesis of $\alpha$-alkyl $\alpha$-amino acid esters in the presence of Sc(III)catalyst (2, Scheme 1).

In an initial study, we chose $N$-arylglycine esters 1a as the model substrates with benzylboronic acid esters ${ }^{9} \mathbf{2 a}$ as alkylation reagents, $\mathrm{PPh}_{3}$ as the ligand, and $\mathrm{BQ}$ as the oxidant in the presence of $10 \mathrm{~mol} \% \mathrm{Cu}(\mathrm{OTf})_{2}$ in DCE at $80{ }^{\circ} \mathrm{C}$. We were pleased to find that the desired product $\alpha$-alkyl $\alpha$-amino acid ester 3a was observed in $32 \%$ yield (Table 1, entry 1). Encouraged by this result, screening several oxidants (Table 1, entries 2-9) showed that $\mathrm{Ag}_{2} \mathrm{CO}_{3}$ was the best choice, and the yield of $3 a$ improved to $70 \%$ (Table 1 , entry 6 ). When the oxidant was increased to 2 equiv., the yield of $3 a$ reached $78 \%$ (Table 1, entry 11). Subsequently, various solvents were examined and DCE was still found to be the best choice (Table 1 , entries 12-16). Then, a variety of different Lewis acids were investigated, and $\mathrm{Sc}(\mathrm{OTf})_{3}$ proved to be the best with $85 \%$ yield for coupling product 3aa (Table 1, entries 17-21). Furthermore, the control experiment showed that only $15 \%$ yield of the desired product was obtained in the absence of Sc(OTf $)_{3}$ (Table 1, entries 22-23).

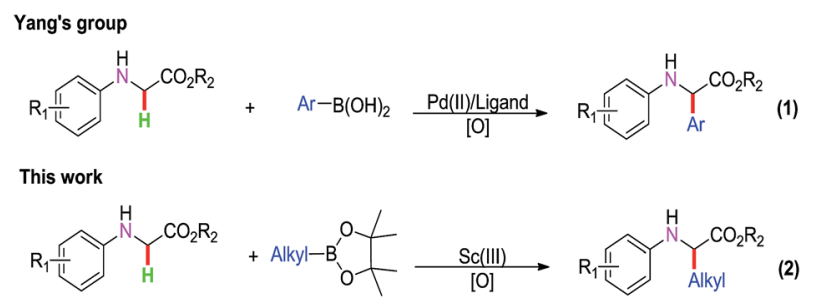

Scheme 1 Reaction of glycine derivatives with metal boron reagents. 
Table 1 Optimization of the reaction conditions ${ }^{a}$

\begin{tabular}{|c|c|c|c|c|c|}
\hline Entry & Catalyst & Ligand & Oxidant & Solvent & Yield $^{b}$ \\
\hline 1 & $\mathrm{Cu}(\mathrm{OTf})_{2}$ & $\mathrm{PPh}_{3}$ & BQ & DCE & $32 \%$ \\
\hline 2 & $\mathrm{Cu}(\mathrm{OTf})_{2}$ & $\mathrm{PPh}_{3}$ & DDQ & DCE & ND \\
\hline 3 & $\mathrm{Cu}(\mathrm{OTf})_{2}$ & $\mathrm{PPh}_{3}$ & ТВHP & DCE & Trace \\
\hline 4 & $\mathrm{Cu}(\mathrm{OTf})_{2}$ & $\mathrm{PPh}_{3}$ & $\mathrm{PhI}(\mathrm{OAc})_{2}$ & DCE & Trace \\
\hline 5 & $\mathrm{Cu}(\mathrm{OTf})_{2}$ & $\mathrm{PPh}_{3}$ & DCP & DCE & $43 \%$ \\
\hline 6 & $\mathrm{Cu}(\mathrm{OTf})_{2}$ & $\mathrm{PPh}_{3}$ & $\mathrm{Ag}_{2} \mathrm{CO}_{3}$ & DCE & $70 \%$ \\
\hline 7 & $\mathrm{Cu}(\mathrm{OTf})_{2}$ & $\mathrm{PPh}_{3}$ & $\mathrm{AgOAc}$ & DCE & $68 \%$ \\
\hline 8 & $\mathrm{Cu}(\mathrm{OTf})_{2}$ & $\mathrm{PPh}_{3}$ & $\mathrm{Ag}_{2} \mathrm{O}$ & DCE & $53 \%$ \\
\hline 9 & $\mathrm{Cu}(\mathrm{OTf})_{2}$ & $\mathrm{PPh}_{3}$ & $\mathrm{AgNO}_{3}$ & DCE & ND \\
\hline $10^{c}$ & $\mathrm{Cu}(\mathrm{OTf})_{2}$ & $\mathrm{PPh}_{3}$ & $\mathrm{Ag}_{2} \mathrm{CO}_{3}$ & DCE & $72 \%$ \\
\hline $11^{d}$ & $\mathrm{Cu}(\mathrm{OTf})_{2}$ & $\mathrm{PPh}_{3}$ & $\mathrm{Ag}_{2} \mathrm{CO}_{3}$ & DCE & $78 \%$ \\
\hline $12^{d}$ & $\mathrm{Cu}(\mathrm{OTf})_{2}$ & $\mathrm{PPh}_{3}$ & $\mathrm{Ag}_{2} \mathrm{CO}_{3}$ & $\mathrm{CH}_{3} \mathrm{CN}$ & $11 \%$ \\
\hline $13^{d}$ & $\mathrm{Cu}(\mathrm{OTf})_{2}$ & $\mathrm{PPh}_{3}$ & $\mathrm{Ag}_{2} \mathrm{CO}_{3}$ & NMP & ND \\
\hline $14^{d}$ & $\mathrm{Cu}(\mathrm{OTf})_{2}$ & $\mathrm{PPh}_{3}$ & $\mathrm{Ag}_{2} \mathrm{CO}_{3}$ & TOL & $13 \%$ \\
\hline $15^{d}$ & $\mathrm{Cu}(\mathrm{OTf})_{2}$ & $\mathrm{PPh}_{3}$ & $\mathrm{Ag}_{2} \mathrm{CO}_{3}$ & DMF & $15 \%$ \\
\hline $16^{d}$ & $\mathrm{Cu}(\mathrm{OTf})_{2}$ & $\mathrm{PPh}_{3}$ & $\mathrm{Ag}_{2} \mathrm{CO}_{3}$ & Dioxane & $23 \%$ \\
\hline $17^{d}$ & $\mathrm{Zn}(\mathrm{OTf})_{2}$ & $\mathrm{PPh}_{3}$ & $\mathrm{Ag}_{2} \mathrm{CO}_{3}$ & DCE & $81 \%$ \\
\hline $18^{d}$ & $\mathrm{Ni}(\mathrm{OTf})_{2}$ & $\mathrm{PPh}_{3}$ & $\mathrm{Ag}_{2} \mathrm{CO}_{3}$ & DCE & $33 \%$ \\
\hline $19^{d}$ & $\mathrm{Al}(\mathrm{OTf})_{2}$ & $\mathrm{PPh}_{3}$ & $\mathrm{Ag}_{2} \mathrm{CO}_{3}$ & DCE & $79 \%$ \\
\hline $20^{d}$ & $\mathrm{Fe}(\mathrm{OTf})_{2}$ & $\mathrm{PPh}_{3}$ & $\mathrm{Ag}_{2} \mathrm{CO}_{3}$ & DCE & $56 \%$ \\
\hline $\mathbf{2 1}^{d}$ & $\mathrm{Sc}(\mathrm{OTf})_{3}$ & $\mathbf{P P h}_{3}$ & $\mathrm{Ag}_{2} \mathrm{CO}_{3}$ & DCE & $85 \%$ \\
\hline $22^{d}$ & & & $\mathrm{Ag}_{2} \mathrm{CO}_{3}$ & DCE & $10 \%$ \\
\hline 23 & $\mathrm{Sc}(\mathrm{OTf})_{3}$ & & & DCE & $15 \%$ \\
\hline
\end{tabular}

${ }^{a}$ Reaction conditions: $1 \mathrm{a}(0.3 \mathrm{mmol}), \mathbf{2 a}$ (1.3 equiv.), catalyst (10 mol\%), ligand (10 mol\%) and oxidant (1.1 equiv.) were stirred in solvent $(1 \mathrm{~mL})$ at $80{ }^{\circ} \mathrm{C}$ under $\mathrm{Ar}$ for $20 \mathrm{~h}^{b}{ }^{b}$ Yield of the isolated product. ${ }^{c}$ Oxidant $(1.5$ equiv.). ${ }^{d}$ Oxidant (2.0 equiv.).

Under the optimized reaction conditions (Table 1, entry 21), the reaction scope was examined as shown in Table 2. We first surveyed various $N$-para-bromophenyl protected glycine esters. It was found that various alkyl esters including methyl $\mathbf{1 b}$ and tert-butyl 1c were well tolerated in the oxidative $\mathrm{C}-\mathrm{H}$ functionalization with $N$-arylglycine esters 1a, affording $\alpha$-alkyl $\alpha$-amino acid esters $\mathbf{3 a}-\mathbf{3 c}$ in $78-85 \%$ yields (Table 2, entries $\mathbf{3 a}-\mathbf{3 c}$ ). Meanwhile, different substituents on the aniline fragment, which bear electron-withdrawing or electron-donating groups, afforded the corresponding desired products in moderate to excellent yields (Table 2, entries 3d-3g). However, the electronic effect in this transformation was very notable, for example, when the aniline fragment changed to $\mathrm{N}$-para-methoxyphenyl, the corresponding product was obtained only in $22 \%$ yield; no substituent on the aniline fragment afforded the desired product in moderate yield (Table 2 , entries $3 \mathbf{g}-\mathbf{3 h}$ ). In order to further expand the substrate scope, we selected the $\mathrm{N}$-parabromophenyl glycine ethyl ester as the substrate, and prepared a few substrates containing substituents with electron-donating or electron-withdrawing effects on other positions of the benzyl group from the available starting materials. The corresponding $\alpha$-amino acid ester products were obtained in good to excellent yields (Table 2, entries 3i-3p). Furthermore, the naphthylboronic acid ester could also undergo transformation and afford the product in $68 \%$ yield (Table 2,31 ).
Table 2 Scope of synthesis of various $\alpha$-amino acid esters ${ }^{a b}$

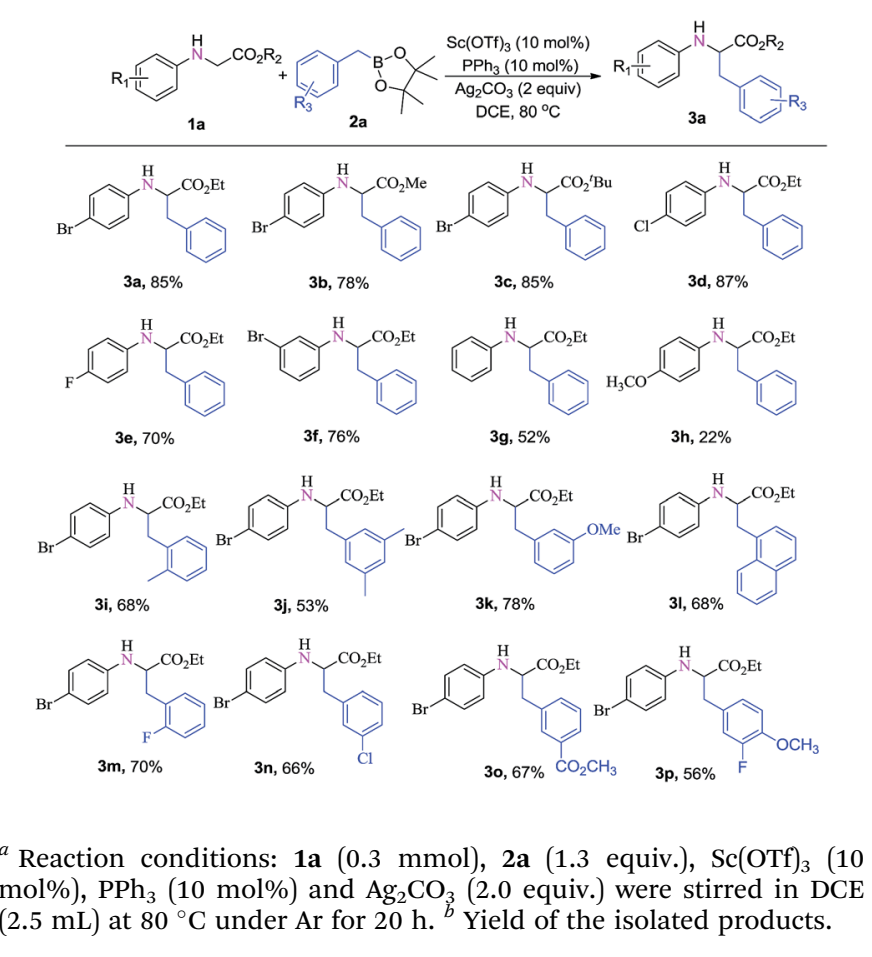

Moreover, to extend the scope of this catalytic system, we carried out direct functionalization of the $\alpha$-peptido $\mathrm{C}-\mathrm{H}$ bonds under the optimized reaction conditions. We were pleased to find that the corresponding $\alpha$-alkylation product 4 aa was obtained in good yield (Scheme 2). We believe that the yield of the product will increase accordingly, after appropriate optimization of the catalytic system. This work is currently under way in our laboratory.

To investigate the mechanism of this transformation, experiments were carried out. The desired product was not observed when 1.0 equivalent of the radical-trapping reagent 2,2,6,6-tetramethyl-1-piperidinyloxy (TEMPO) was used under standardized reaction conditions. At the same time, we found that when 2,6-di-tert-butyl-4-methylphenol (BHT), a radical scavenger, was introduced into the reaction system, the yield of product 3a decreased dramatically from $85 \%$ to $8 \%$ (Scheme 3 ). To our delight, BHT trapped the key intermediate, which was detected by GC-MS (see ESI†). This result suggests that the reaction may proceed via a radical mechanism (Scheme 4). First, benzylboronic acid ester $\mathbf{2 a}$ forms the intermediate benzyl radical 5 under the oxidation of $\mathrm{Ag}_{2} \mathrm{CO}_{3}$; at the same time, radical 6 is generated by abstracting an $\alpha$ hydrogen atom from $N$-arylglycine ester 1a under oxidant. Then the product 3aa is obtained through the radical addition reaction (Scheme 4, path

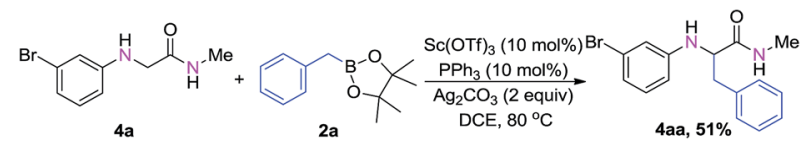

Scheme 2 Extending the scope of the catalytic system. 


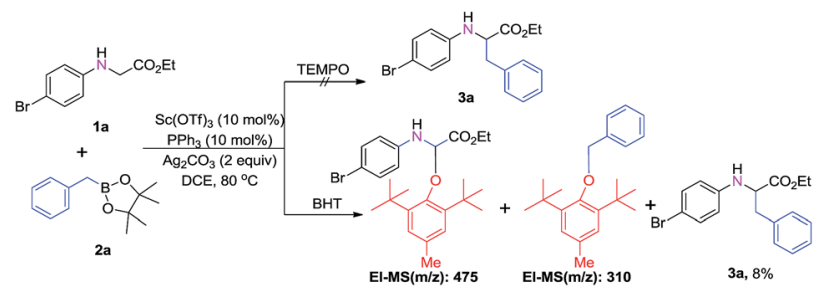

Scheme 3 Radical-trapping experiment.

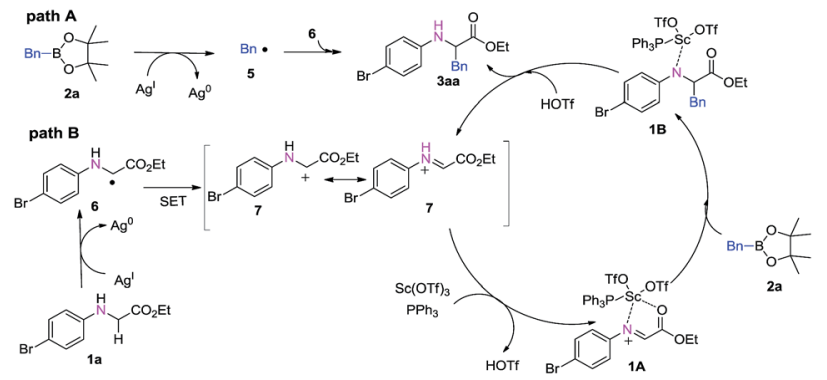

Scheme 4 Proposed mechanism.

A). Then, single-electron transfer (SET) occurs from 6 to cation 7, which can tautomerize to the iminium ion. At the same time, $\mathrm{Sc}(\mathrm{OTf})_{3}$ with the ligand $\mathrm{PPh}_{3}$ reacts as a Lewis acid with 7 to form the active species intermediate 1A. Then intermediate 1B is produced though Petasis-type addition of benzylic boronic acid 2a to the iminium intermediate. ${ }^{6,10}$ Finally, product $\mathbf{3 a a}$ is obtained upon dissociation in the presence of HOTf, and the active scandium catalyst is regenerated and enters the next catalytic cycle synchronously (Scheme 4, path B).

In conclusion, we have developed a mild and economical $\mathrm{Sc}(\mathrm{OTf})_{3}$-catalyzed oxidative cross-coupling reaction for the synthesis of a series of $\alpha$-alkyl $\alpha$-amino acid ester derivatives. Further applications of this approach to other substrates and enantioselective reactions are being investigated in our laboratory.

\section{Acknowledgements}

This work was financially supported by the National Natural Science Foundation of China (No. 21462035), the Fundamental Research Funds for the Central Universities (31920160050), the Scientific Research Foundation of Northwest University for Nationalities (xbmuyjrc201603), and the Gansu Provincial Council for Science and Technology (144GKCA031).

\section{Notes and references}

1 (a) S. H. Cho, J. Y. Kim, J. Kwak and S. Chang, Chem. Soc. Rev., 2011, 40, 5068-5083; (b) S. A. Girard, T. Knauber and C.-J. Li, Angew. Chem., Int. Ed., 2014, 53, 74-100; (c) C.-J. Li, Acc. Chem. Res., 2009, 42, 335-344; (d) C.-J. Li and Z. Li, in Pure and Applied Chemistry, vol. 78, 2006, p. 935; (e) C. J. Scheuermann, Chem.-Asian J., 2010, 5, 436-451; $(f)$
C. S. Yeung and V. M. Dong, Chem. Rev., 2011, 111, 12151292.

2 (a) R. M. Williams and J. A. Hendrix, Chem. Rev., 1992, 92, 889-917; (b) S. Hunt, in Chemistry and Biochemistry of the Amino Acids, ed. G. C. Barrett, Chapman and Hall, London, 1985, p. 55; (c) R. M. Williams and C. M. Burnett, New Tricks in Amino Acid Synthesis: Applications to Complex Natural Products, ACS, Washington, DC, 2009, p. 420; (d) Amino Acids, Peptides and Proteins in Organic Chemistry, ed. B. H. Andrew, Wiley-VCH, Weinheim, Germany, 2011.

3 (a) L. Zhao and C.-J. Li, Angew. Chem., Int. Ed., 2008, 47, 70757078; (b) J. Xie and Z.-Z. Huang, Angew. Chem., Int. Ed., 2010, 49, 10181-10185; (c) J. S. Bandar and T. H. Lambert, J. Am. Chem. Soc., 2013, 135, 11799-11802; (d) J. T. Binder, C. J. Cordier and G. C. Fu, J. Am. Chem. Soc., 2012, 134, 17003-17006; (e) C. Huo, C. Wang, M. Wu, X. Jia, H. Xie and Y. Yuan, Adv. Synth. Catal., 2014, 356, 411-415; $(f)$ C. Huo, M. Wu, F. Chen, X. Jia, Y. Yuan and H. Xie, Chem. Commun., 2015, 51, 4708-4711; (g) C. Huo, H. Xie, F. Chen, J. Tang and Y. Wang, Adv. Synth. Catal., 2016, 358, 724730; (h) S. Kotha, Acc. Chem. Res., 2003, 36, 342-351; (i) C. Nájera and J. M. Sansano, Chem. Rev., 2007, 107, 45844671; (j) S. Saito, T. Tsubogo and S. Kobayashi, J. Am. Chem. Soc., 2007, 129, 5364-5365; (k) M. Salman, Z.-Q. Zhu and Z.-Z. Huang, Org. Lett., 2016, 18, 1526-1529; (l) B. M. Trost and F. Miege, J. Am. Chem. Soc., 2014, 136, 3016-3019; (m) M. Wan, H. Lou and L. Liu, Chem. Commun., 2015, 51, 13953-13956; (n) E. W. Werner, T.-S. Mei, A. J. Burckle and M. S. Sigman, Science, 2012, 338, 1455-1458; (o) Z.-Y. Xue, Q.-H. Li, H.-Y. Tao and C.-J. Wang, J. Am. Chem. Soc., 2011, 133, 11757-11765; (p) Z.-Q. Zhu, P. Bai and Z.-Z. Huang, Org. Lett., 2014, 16, 4881-4883; $(q)$ C. Huo, Y. Yuan, F. Chen and Y. Wang, Adv. Synth. Catal., 2015, 357, 3648-3654; (r) C. Huo, H. Xie, C. Yang, J. Dong and Y. Wang, Tetrahedron Lett., 2016, 57, 2179-2182; $(s)$ L. Li, Q. Wang, P. Liu, H. Meng, X.-L. Kan, Q. Liu and Y.-L. Zhao, Org. Biomol. Chem., 2016, 14, 165171; $(t)$ G. Liu, J. Qian, J. Hua, F. Cai, X. Li and L. Liu, Org. Biomol. Chem., 2016, 14, 1147-1152; (u) X.-X. Liu, Z.-Y. Wu, Y.-Q. He, X.-Q. Zhou, T. Hu, C.-W. Ma and G.-S. Huang, Adv. Synth. Catal., 2016, 358, 2385-2391; (v) X. Yang, L. Li, Y. Li and Y. Zhang, J. Org. Chem., 2016, 81, 12433-12442.

4 (a) P. Liu, Y. Li, H. Wang, Z. Wang and X. Hu, Tetrahedron Lett., 2012, 53, 6654-6656; (b) P. Liu, Z. Wang, J. Lin and X. Hu, Eur. J. Org. Chem., 2012, 2012, 1583-1589; (c) H. Richter and O. García Mancheño, Org. Lett., 2011, 13, 6066-6069; (d) R. Rohlmann, T. Stopka, H. Richter and O. García Mancheño, J. Org. Chem., 2013, 78, 6050-6064; (e) Z.-Q. Wang, M. Hu, X.-C. Huang, L.-B. Gong, Y.-X. Xie and J.-H. Li, J. Org. Chem., 2012, 77, 8705-8711; (f) W.-T. Wei, R.-J. Song and J.-H. Li, Adv. Synth. Catal., 2014, 356, 17031707; (g) L. Zhao, O. Baslé and C.-J. Li, Proc. Natl. Acad. Sci. U. S. A., 2009, 106, 4106-4111.

5 (a) M.-X. Cheng, R.-S. Ma, Q. Yang and S.-D. Yang, Org. Lett., 2016, 18, 3262-3265; (b) Y.-Y. Huang, C. Cai, X. Yang, Z.-C. Lv and U. Schneider, ACS Catal., 2016, 6, 5747-5763; (c) Z. Meng, S. Sun, H. Yuan, H. Lou and L. Liu, Angew. Chem., 
Int. Ed., 2014, 53, 543-547; (d) S. Stockerl and O. G. Mancheno, Org. Chem. Front., 2016, 3, 277-280; (e) S. Sun, C. Li, P. E. Floreancig, H. Lou and L. Liu, Org. Lett., 2015, 17, 1684-1687; (f) S. Sun, Y. Mao, H. Lou and L. Liu, Chem. Commun., 2015, 51, 10691-10694; $(g)$ X.-H. Wei, G.-W. Wang and S.-D. Yang, Chem. Commun., 2015, 51, 832-835; (h) Z. Xie, X. Zan, S. Sun, X. Pan and L. Liu, Org. Lett., 2016, 18, 3944-3947; (i) J. Chen, X. Lu, W. Lou, Y. Ye, H. Jiang and W. Zeng, J. Org. Chem., 2012, 77, 8541-8548; (j) A. Córdova, Acc. Chem. Res., 2004, 37, 102-112; $(k)$ N. Gommermann, C. Koradin, K. Polborn and P. Knochel, Angew. Chem., Int. Ed., 2003, 42, 5763-5766; (l) M. Hatano, T. Horibe and K. Ishihara, J. Am. Chem. Soc., 2009, 132, 5657; $(m)$ K. R. Knudsen, T. Risgaard, N. Nishiwaki, K. V. Gothelf and K. A. Jørgensen, J. Am. Chem. Soc., 2001, 123, 5843-5844; (n) S. Kobayashi, T. Hamada and K. Manabe, J. Am. Chem. Soc., 2002, 124, 5640-5641; (o) S. Kobayashi, Y. Mori, J. S. Fossey and M. M. Salter, Chem. Rev., 2011, 111, 2626-2704; (p) C. Koradin, K. Polborn and P. Knochel, Angew. Chem., Int. Ed., 2002, 41, 2535-2538; (q) T. Beisel, A. M. Diehl and G. Manolikakes, Org. Lett., 2016, 18, 4116-4119; (r) A. E. Taggi, A. M. Hafez and T. Lectka, Acc. Chem. Res., 2002, 36, 10-19; $(s)$ B. M. Trost and L. R. Terrell, J. Am. Chem. Soc., 2002, 125, 338-339; $(t)$ C. Wei and C.-J. Li, J. Am. Chem. Soc., 2002, 124, 56385639; (u) C. Wei, J. T. Mague and C.-J. Li, Proc. Natl. Acad. Sci. U. S. A., 2004, 101, 5749-5754; (v) C.-Y. Zhou, S.-F. Zhu,
L.-X. Wang and Q.-L. Zhou, J. Am. Chem. Soc., 2010, 132, 10955-10957; (w) Z. Xie, X. Liu and L. Liu, Org. Lett., 2016, 18, 2982-2985.

6 G. Zhang, Y. Zhang and R. Wang, Angew. Chem., Int. Ed., 2011, 50, 10429-10432.

7 (a) K. Chen, F. Hu, S.-Q. Zhang and B.-F. Shi, Chem. Sci., 2013, 4, 3906-3911; (b) J. He, S. Li, Y. Deng, H. Fu, B. N. Laforteza, J. E. Spangler, A. Homs and J.-Q. Yu, Science, 2014, 343, 1216-1220; (c) Q. Zhang, K. Chen, W. Rao, Y. Zhang, F.-J. Chen and B.-F. Shi, Angew. Chem., Int. Ed., 2013, 52, 13588-13592; (d) S.-Y. Zhang, Q. Li, G. He, W. A. Nack and G. Chen, J. Am. Chem. Soc., 2013, 135, 12135-12141.

8 Z. Xie, J. Jia, X. Liu and L. Liu, Adv. Synth. Catal., 2016, 358, 919-925.

9 (a) A. Giroux, Tetrahedron Lett., 2003, 44, 233-235; (b) T. Liu, X. Shao, Y. Wu and Q. Shen, Angew. Chem., Int. Ed., 2012, 51, 540-543.

10 (a) T. Thaima and S. G. Pyne, Org. Lett., 2015, 17, 778-781; (b) R. Frauenlob, C. Carcía, G. A. Bradshaw, H. M. Burke and E. Bergin, J. Org. Chem., 2012, 77, 4445-4449; (c) F. Yang, K.-G. Ji, S. Ali and Y.-M. Liang, J. Org. Chem., 2011, 76, 8329-8335; (d) S. Kobayashi and S. Nagayama, J. Org. Chem., 1997, 62, 232-233; (e) B. Kang, A. W. Miller, S. Goyal and S. T. Nguyen, Chem. Commun., 2009, 39283930; $(f)$ S. Lee, W. L. Lee and J. Yun, Adv. Synth. Catal., 2015, 357, 2219-2222. 